\title{
Numerical Study on the Stress of Pile Foundation Influenced by the Beaded Karst
}

\author{
Shanxiong Chen ${ }^{\mathrm{a}}$, Xichang Xu, Zhangjun Dai, Haibin Xu \\ State Key Laboratory of Geomechanics and Geotechnical Engineering, Institute of Rock and Soil \\ Mechanics, Chinese Academy of Sciences, Wuhan, 430071, China \\ aemail:sxchen@whrsm.ac.cn
}

\section{Keywords: Beaded Karst; Pile Foundation; Negative Side Friction; Axial Force}

\begin{abstract}
Selecting a reasonable pile type and the pile foundation bearing stratum is important to design and construction in the karst area. It is needed to analyze the stress of pile foundation according to different types of karst caves. By numerical simulation, it is found that under the influence of the settlement of the karst cave filling, negative side friction appears in the area of the karst cave. The more the number of karst cave, the more increase the axial force of the pile. The larger the cave width, or the smaller the cave spacing, the smaller the positive side friction in the cave area. The larger the cave width, the more slowly the axial force decline. With the decrease of the cave spacing, the axial force of the pile under the same depth has an increasing trend.
\end{abstract}

\section{Introduction}

Selecting the reasonable pile type and the pile foundation bearing stratum is the key to design under the bridge construction in the karst area[1][2]. According to the geological conditions and the stress in different ways, the pile can be rock socketed pile or friction pile[3]. In the karst area, because the formation is inconsistent, and the location, size and depth of karst cave are greatly changed. Design often in accordance with each pile hole drilling data that provided from the geological survey, and analyse each pile, according to the changes in the underground karst for pile foundation design.Therefore, it is needed to analyze the stress of pile foundation according to different types of karst caves[4-7]. In this paper, based on the ANSYS finite element numerical simulation software, according to the actual engineering characteristics, we discusses the effect of the number, spacing, size and other factors of karst cave on the force of pile foundation. It can provide reference for the design and construction of pile foundation in beaded karst region.

\section{Numerical Calculation Scheme}

In ANSYS, using the axisymmetric model, carry out the numerical simulation research on the pile foundation and the cave. To reflect the interaction between the pile foundation and the formation, contact elements are set between the pile foundation and formation, calculation model is shown in Figure 1. Material parameters are shown in table 1.

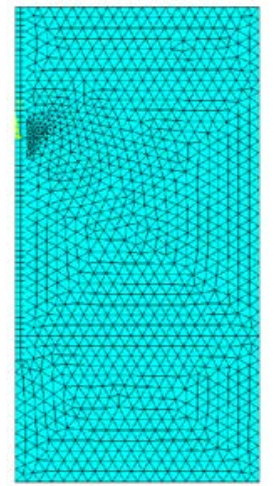

Fig. 1 calculation model and contact elements 
Table 1 Calculation parameters

\begin{tabular}{|c|c|c|c|c|c|c|}
\hline Material & Lithology & $\begin{array}{c}\text { Density } \\
/ \mathrm{kN} / \mathrm{m}^{3}\end{array}$ & $\begin{array}{c}\text { Elastic modulus } \\
/ \mathrm{MPa}\end{array}$ & Poisson ratio & $\begin{array}{c}c \\
/ \mathrm{kPa}\end{array}$ & $\begin{array}{c}\varphi \\
{ }^{\circ}\end{array}$ \\
\hline Foundation 1 & Pebble & 21 & 50 & 0.27 & 10 & 40 \\
\hline Foundation 2 & Medium weathered rock & 22 & 180 & 0.26 & 80 & 35 \\
\hline Foundation 3 & Slightly weathered rock & 23 & 1000 & 0.23 & 150 & 40 \\
\hline Pile & C40 Reinforced concrete & 26 & 32500 & 0.20 & - & - \\
\hline Karst cave & Soft filler & 13 & 10 & 0.4 & 5 & $8 \sim 10$ \\
\hline
\end{tabular}

Take the load of pile foundation and the upper load of pile foundation $624 \mathrm{kPa}$ into consideration in the calculation. It is divided into the following conditions: The number of karst cave is respectively $1,2,3$, the diameter is $3.6 \mathrm{~m}$, the spacing is $1.8 \mathrm{~m}$; The number of karst cave is 3 , the height is $3.6 \mathrm{~m}$, the width is respectively $2.4 \mathrm{~m}, 3.6 \mathrm{~m}, 4.8 \mathrm{~m}$, the spacing is $1.8 \mathrm{~m}$; The number of karst cave is 3 , the diameter is $3.6 \mathrm{~m}$, the spacing is respectively $0.6 \mathrm{~m}, 1.2 \mathrm{~m}, 1.8 \mathrm{~m}$.

\section{Analysis of the Influence of the Cave Quantity on the Pile Foundation Stress}

Because the caves are filled with soft material, the settlement rate is higher than that of the rigid pile, this will lead to uneven settlement, which is detrimental to the pile stress.

The side friction of pile influenced by the number of the karst cave is shown in Figure 2.

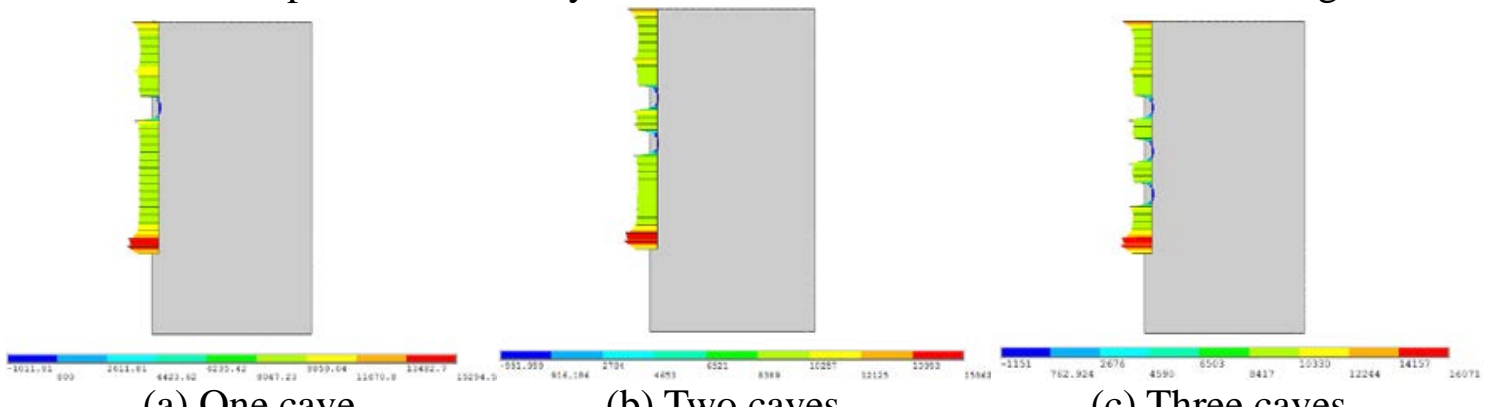

(a) One cave

(b) Two caves

(c) Three caves

Fig. 2 The side friction of pile influenced by the cave quantity

Under the pile body weight and the upper load, the distribution of the side friction along the depth for single cave is consistent with that for two or three caves. The side friction distribution and quantity values are similar under two and three caves conditions. Under the influence of the settlement of the karst cave, negative friction appears in the area of the karst cave, the maximum negative side friction appears in the middle of the karst caves, which are respectively 0.951 and $1.151 \mathrm{kPa}$ under two and three caves, and then the negative side friction decreases to both sides, until it become positive side friction.

Figure 3 shows the effect of different quantity of karst cave on the axial force of pile in upper load and cave effect load stages. Under the upper load of pile foundation, the axial force at the top of pile is maximum, and it decreases with depth, it is minimum at bottom. When reduce the elastic modulus of the soft filling in the caves, the cave filling consolidation settlement leads to the pile axial force suddenly reversely increases, when the axial force increases to a certain value, then pile force decrease with the depth. Cave consolidation settlement significantly increases the axial force of the pile. The more the number of karst cave, the more increase the axial force of the pile.

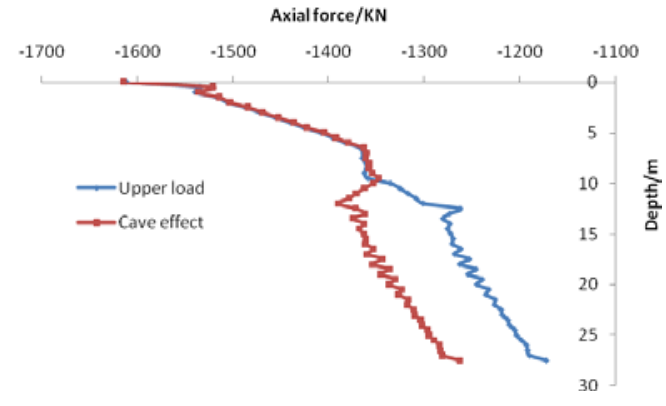

(a)One cave

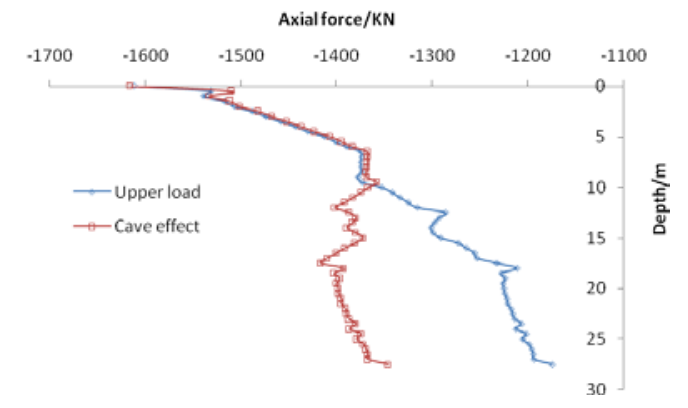

(b) Two caves 


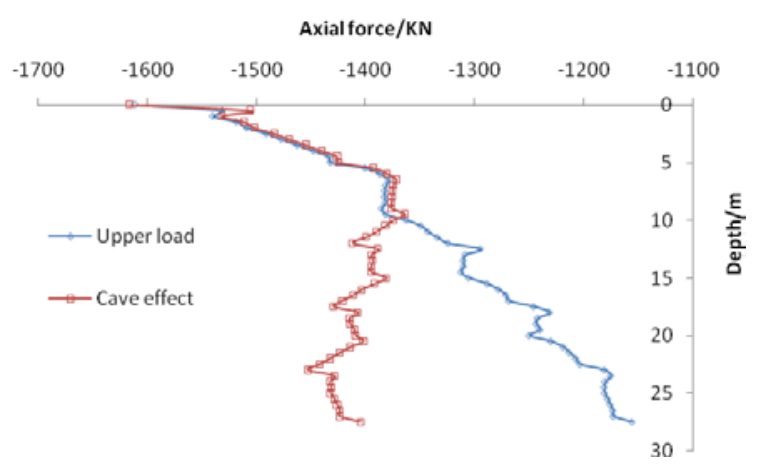

(c) Three caves

Fig. 3 The effect of cave quantity on the axial force of the pile

\section{Analysis of the Influence of the Cave Size on the Pile Foundation Stress}

The side friction of pile influenced by the size of the karst cave is shown in Figure 4.

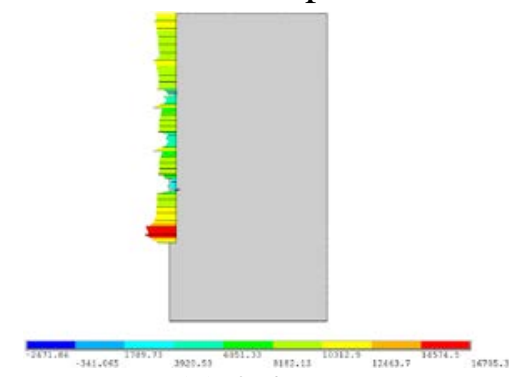

(a) $2.4 \mathrm{~m}$

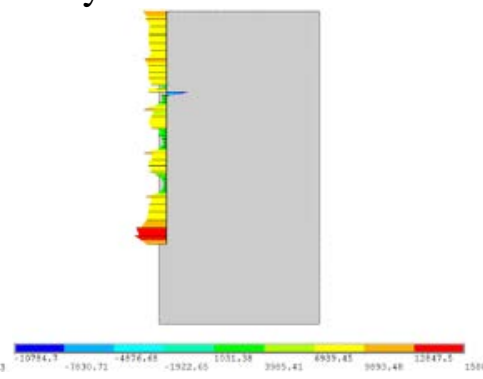

(b) $3.6 \mathrm{~m}$

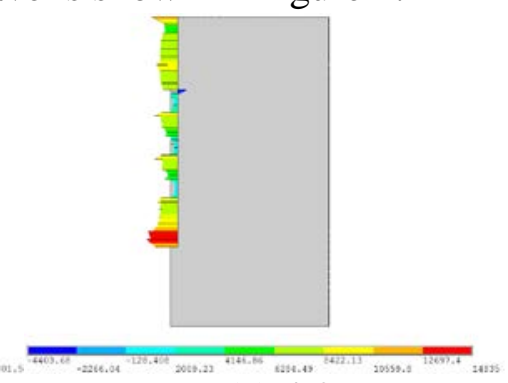

(c) $4.8 \mathrm{~m}$

Fig. 4 The side friction of pile influenced by the cave width

Under the load of the pile and the upper load, the larger the cave width, the smaller the positive side friction in the karst area, namely, the negative side friction effect is larger, and the negative side friction effect is the largest when the width is $4.8 \mathrm{~m}$. The positive side friction in the cave area reduces under the influence of the cave consolidation settlement, and the larger the cave width, the smaller the positive side friction in the cave area, The cave with the width of $4.8 \mathrm{~m}$ has the minimum positive side friction, and the effect of negative side friction is the most obvious.

Figure 5 shows the effect of different width of karst cave on the axial force of pile in upper load and cave effect load stages.

Under the upper load, the axial force of pile decreases with the depth increases, and the larger the width of the cave, the larger the axial force of pile in the same depth. Under the influence of cave settlement, the pile axial force decreasing trend abates, in a certain extent increases the axial force of pile, it is to say that the soft filling material consolidation settlement in the cave has a significantly effect to the negative side friction of pile, and the bigger the cave width, the more slowly the axial force decline, when the width is $4.8 \mathrm{~m}$, the axial force declines to certain degree, then remains almost unchanged.

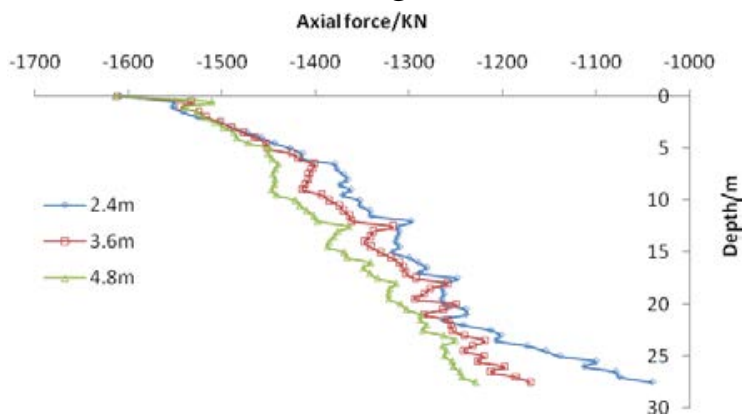

(a) Upper load

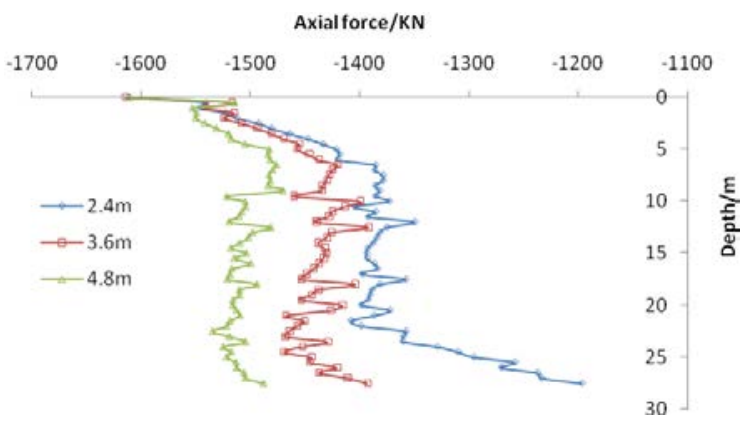

(b) Cave effect

Fig. 5 The effect of cave width on the axial force of the pile 


\section{Analysis of the Influence of the Cave Spacing on the Pile Foundation Stress}

The side friction of pile influenced by the spacing of the karst cave is shown in Figure 6.

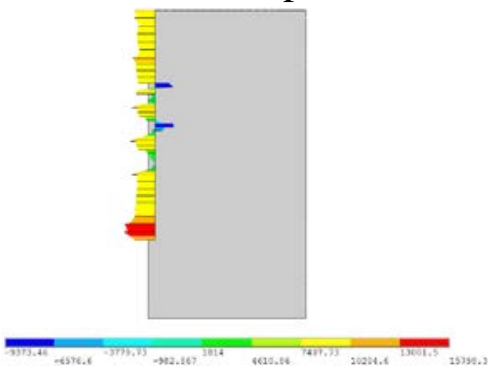

(a) $0.6 \mathrm{~m}$

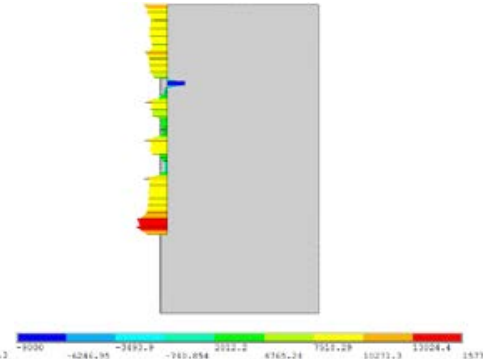

(b) $1.2 \mathrm{~m}$

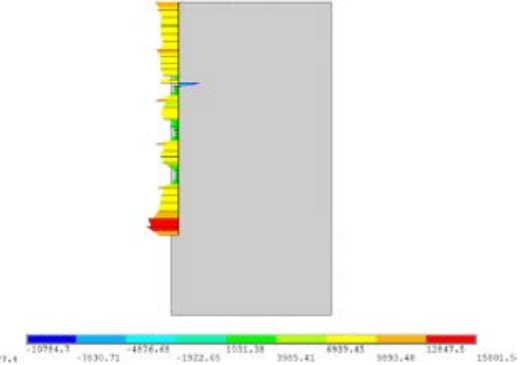

(c) $1.8 \mathrm{~m}$

Fig. 6 The side friction of pile influenced by the cave spacing

Under the load of the pile and the upper load, the smaller the cave spacing, the smaller the positive side friction in the karst area, namely, the negative side friction effect is larger, and the negative side friction effect is the largest when the spacing is $0.6 \mathrm{~m}$. The positive side friction in the cave area reduces under the influence of the cave consolidation settlement, and the smaller the cave spacing, the smaller the positive side friction in the cave area, The cave with the spacing of $0.6 \mathrm{~m}$ has the minimum positive side friction, and the effect of negative side friction is the most obvious.

Figure 7 shows the effect of different spacing of karst cave on the axial force of pile in upper load and cave effect load stages.

Under the upper load, the axial force of pile decreases with the depth increases, and the axial force of the pile under the three spacing is not quite different. Under the influence of cave settlement, the pile axial force decreasing trend abates, in a certain extent increases the axial force of pile, it is to say that the soft filling material consolidation settlement in the cave has a significantly effect to the negative side friction of pile, and with the decrease of the cave spacing, the axial force of the pile under the same depth has an increasing trend, compared to the $1.2 \mathrm{~m}, 1.8 \mathrm{~m}$ cave spacing, the axial force of pile is larger when the spacing is $0.6 \mathrm{~m}$.

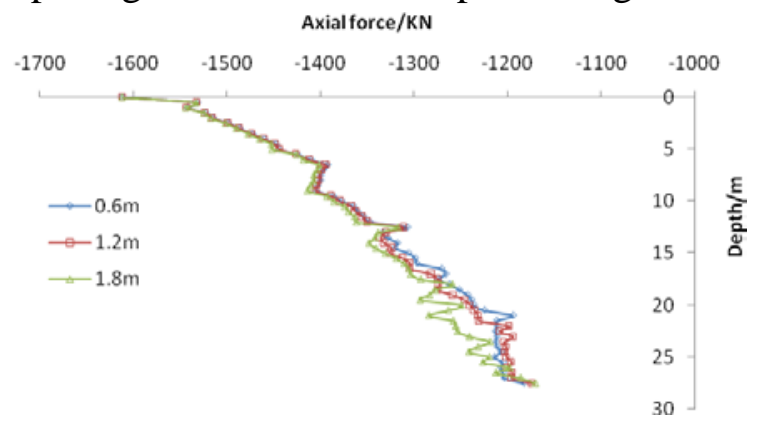

(a) Upper load

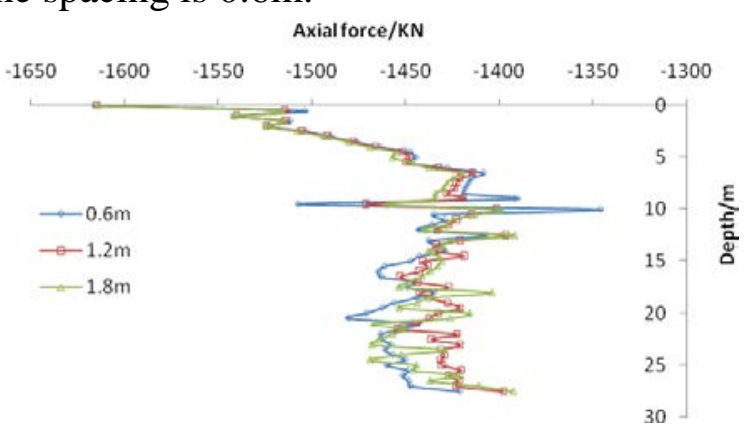

(b) Cave effect

Fig. 7 The effect of cave spacing on the axial force of the pile

\section{Conclusion}

Under the influence of the settlement of the karst cave filling, negative friction appears in the area of the karst cave. The more the number of karst cave, the more increase the axial force of the pile. The positive side friction in the cave area reduces under the influence of the cave consolidation settlement, the larger the cave width, or the smaller the cave spacing, the smaller the positive side friction in the cave area. The larger the cave width, the more slowly the axial force decline. With the decrease of the cave spacing, the axial force of the pile under the same depth has an increasing trend.

\section{References}

[1] Zhao, M. H., Cao, W. G., Peng-Xiang, H. E., \& Yang, M. H. Study on safe thickness of rock mass at end of bridge foundation's pile in karst and worked-out mine area[J]. Rock \& Soil 
Mechanics. 2004.

[2] Yi, J., He, G. J., Liu, S. S., Li, Z. Y., \& Zheng, Z. E. Construction method and numerical analysis on the bearing capacity of the large diameter and abyssal pile located in complex karst area[J]. Advanced Materials Research, 2013 639-640, 688-693.

[3] Zheng, W. G., Xie, Y. C., \& Xue, X. B. Selection of pile foundations in karst areas[J]. Yantu Gongcheng Xuebao/chinese Journal of Geotechnical Engineering, 2011 33, 404-407.

[4] Poulos, H. G., Small, J. C., \& Chow, H. Foundation design for high-rise tower in karstic ground[J]. Geotechnical Special Publication, 2013 (229) 720-731.

[5] Sun, Y., Zhang, Z., \& Zhang, H. Analysis on parameter sensitivity of pile foundations stability in karst areas based on the theory of grey relation[J]. Chinese Journal of Underground Space \& Engineering, 9(2), 2013 297-303.

[6] Hua, S., \& Engineering, D. O. Numerical simulation research on the stability of transmission tower pile foundations in a karst area of guangdong province[J]. Carsologica Sinica, 2014 33(1), 44-50.

[7] Niu, J., Oyediran, I. A., Liu, D., Huang, X., Cui, Z., \& Wang, H., et al. Quantitative foundation stability evaluation of urban karst area: case study of tangshan, china[J]. Soils and Foundations, 2015 55(3), 493-503. 